\title{
Correlation between the development of extracolonic manifestations in FAP patients and mutations beyond codon 1403 in the APC gene
}

Zuzana Dobbie, Martina Spycher, Jean-Luc Mary, Michèle Häner, Irene Guldenschuh, Reiner Hürliman, Rudolf Amman, Jürgen Roth, Hansjakob Müller, Rodney J Scott

\begin{abstract}
The APC gene was investigated in 31 unrelated polyposis coli families by SSCP analysis and the protein truncation test. Twenty-three germline mutations were identified which gave rise to a variety of different phenotypes. Some of these mutations have already been described; however we report six previously unpublished mutations. Typical disease symptoms were observed in families who harboured mutations between exon 4 (codon 169) and codon 1393 of exon 15. Mutations beyond codon 1403 were associated with more varied phenotype with respect to the development of extracolonic symptoms. In this report we provide support for the notion that there appears to be a correlation between the location of an APC mutation (beyond codon 1403) and extracolonic manifestations of familial adenomatous polyposis.
\end{abstract}

( $\mathcal{}$ Med Genet 1996;33:274-280)

Key words: polyposis coli; mutation; protein truncation test.

Familial adenomatous polyposis is probably the best defined colorectal cancer syndrome. It is an autosomal dominantly inherited disease characterised by hundreds to thousands of adenomatous polyps in the colon and rectum with a prevalence of approximately 1 in 10000 . The probability that colorectal cancer will develop in untreated FAP patients approaches $100 \%$ by 40 years of age. ${ }^{1}$

Germline mutations in the adenomatous polyposis coli (APC) gene appear to be the initiating event for the development of this disorder. This gene was localised to 5q21-22 and subsequently cloned..$^{2-6}$ It consists of 15 exons, the first 14 of which are relatively short, whereas exon 15 spans over $6.5 \mathrm{~kb}$. The gene encodes a protein of 2843 amino acids. The protein has been shown to form homodimers, such that the first 171 residues are sufficient and the first $\mathbf{4 5}$ amino acids necessary for this interaction. ${ }^{7}$

Two groups ${ }^{89}$ isolated APC protein in association with catenins, a family of intracellular polypeptides which interact with E-cadherin to regulate cell-cell communication. Consequently a catenin binding domain was localised to a triple repeated 15 amino acid consensus sequence in the central region of the protein (between codons 1014 and 1210). Additionally, the APC protein contains multiple binding and regulatory sites for $\beta$-catenin containing a 20 amino acid consensus sequence between amino acids 1342-2075. By downregulation or redistribution of $\beta$-catenin, the APC protein has an important effect on catenin levels within the cell. ${ }^{10-12}$ Finally, two recent studies $^{1314}$ examined the subcellular localisation of the APC protein and showed that the wild type APC protein colocalised with cytoplasmic microtubules whereas mutant APC protein did not. The carboxy-terminal region of the APC protein appears to be essential for this association. Thus, the function of the APC protein could be in signal transmission from catenins to the cytoskeleton and, in turn, from the inside of the cell via catenins to the extracellular matrix. ${ }^{14}$

There is clinical variability in genetically confirmed FAP patients. The APC phenotype is usually determined using two parameters, the number and age of onset of colorectal polyps and the presence or absence of extracolonic manifestations. Variant forms of FAP have been described and are known as either the attenuated form of APC (AAPC) $)^{15}$ or the flat adenoma syndrome. ${ }^{16}$ These are characterised by a smaller number of polyps, later age of onset, and slower evolution of disease. In the reported kindreds, AAPC appears to arise from mutations occurring at the amino-terminus of the APC gene. ${ }^{1718}$ In contrast, other manifestations in addition to colonic polyps may occur, which include polyps of the upper gastrointestinal tract, desmoids, osteomas, fibromas, and lipomas. These symptoms are the hallmarks of the more severe form of the disease (commonly referred to as Gardner's syndrome).

Several different techniques have been used in the analysis of the APC gene, such as single strand conformational polymorphism (SSCP) analysis, denaturing gradient gel electrophoresis (DGGE), or the ribonuclease (RNase) protection assay. The observation that the majority of mutations in the APC gene result in a truncated protein ( $>95 \%$ ) allowed the development of a test based on an examination of the APC gene product. ${ }^{1920}$ The recently developed protein truncation test (PTT) relies on the identification of an artificially created truncated protein using an in vitro transcription and translation assay of genomic PCR products. 
Table 1 Germline mutations in the APC gene and resulting phenotypes in unrelated polyposis coli families

\begin{tabular}{|c|c|c|c|c|c|c|c|c|c|c|c|c|}
\hline \multirow{2}{*}{$\begin{array}{l}\text { Family } \\
\text { No }\end{array}$} & \multirow[t]{2}{*}{$F H / N F$} & \multicolumn{3}{|l|}{ Mutation } & \multicolumn{8}{|l|}{ Phenotype } \\
\hline & & $1-14 / 15$ & Codon & NT change & Polyposis & $R P N$ & $O$ & $L$ & $D$ & $F$ & $S I P$ & $S P$ \\
\hline 1506 & FH & $3 /$ & 99 & cgg-tgg & Mild & A & & & & & & \\
\hline 1464 & FH & $4 /-$ & 151 & del c & Mild & A & & & & & & \\
\hline 11 & FH & $4 /-$ & $169-170$ & del (atag) & + & B & & & & & & \\
\hline 197 & NF & $61-$ & 232 & cga-tga & + & C & & & & & & \\
\hline 1528 & NF & $11 /-$ & 498 & del a & + & B & & & & & & \\
\hline 1382 & FH & $-/ b$ & 793 & del a & + & B-C & & & & & & \\
\hline 215 & FH & $-/ b$ & 805 & cga-tga & + & $\mathrm{C}$ & & & & & & \\
\hline 1468 & $\mathrm{FH}$ & $-/ c$ & 935 & tac-taa & + & B-C & & & & & & \\
\hline 1471 & FH & $-1 e$ & 1061 & del (acaaa) & + & B & & & & & & \\
\hline 1478 & $\mathrm{FH}$ & $-1 e$ & 1061 & del (acaaa) & + & $\mathrm{A}-\mathrm{C}$ & & & & & & \\
\hline 19 & NF & $-/ e$ & 1062 & del (caaa) & + & C & & & & & & \\
\hline 1557 & $\mathrm{FH}$ & $-1 e$ & 1135 & del $t$ & + & $\mathrm{C}$ & & & & & & \\
\hline 1519 & FH & $-/ f$ & 1193 & del (ca) & + & B & & & & & & \\
\hline 114 & FH & $-/ g$ & 1324 & del c & + & B-C & & & & & & \\
\hline 246 & NF & $-/ g$ & 1324 & del c & + & $\bar{B}$ & & & & & & \\
\hline 1539 & $\mathrm{FH}$ & $-/ \mathrm{h}$ & 1373 & del (ac) & + & $\mathrm{C}$ & & & & & & \\
\hline 20 & $\mathrm{FH}$ & $-/ \mathrm{h}$ & 1393 & tca-tga & + & B-C & & & & & & \\
\hline 177 & $\mathrm{FH}$ & $-/ \mathrm{h}$ & 1403 & del c & + & $\mathrm{A}-\mathrm{B}$ & + & & + & & & \\
\hline 2 & $\mathrm{FH}$ & $-/ \mathrm{h}$ & 1450 & cga-tga & + & $\mathrm{B}$ & + & + & & + & & \\
\hline 24 & $\mathrm{FH}$ & $-/ h$ & 1465 & del (ag) & + & C & & & & & + & + \\
\hline 1469 & FH & $-/ \mathbf{n}$ & 1987 & del a & + & $\mathrm{A}-\mathrm{C}$ & + & + & & & + & + \\
\hline 1488 & $\mathrm{FH}$ & $-/ n$ & 1987 & del a & + & C & + & & + & + & & + \\
\hline 1501 & FH & $-/ \mathbf{n}$ & 1987 & del a & + & B & & + & + & & & + \\
\hline
\end{tabular}

$\mathrm{FH}=$ family history of colorectal cancer, $\mathrm{NF}=$ non-familial case.

RPN = range of polyp number: $A$, under $100, B, 100-1000, C$, over 1000 .

$\mathrm{D}=$ desmoid, $\mathrm{L}=$ lipoma, $\mathrm{F}=$ fibroma, $\mathrm{O}=$ osteoma, $\mathrm{SIP}=$ small intestinal polyps, $\mathrm{SP}=$ stomach polyps.

In this report we have used both SSCP and PTT to determine germline mutations in the entire coding region of the APC gene within a set of 31 polyposis coli families. We have correlated these mutations with the phenotypic severity of the disease with respect to the development of extracolonic lesions. Our results indicate that there appears to be a relationship between the site of mutation and the likelihood of more severe disease.

\section{Subjects and methods FAP FAMILIES}

The group of 31 unrelated polyposis coli families were examined for mutations in exon 15 . This included five families (two AAPC and three typical) with previously detected mutations in exons $1-14^{18}$ to ensure that no other causative mutation was present. The 26 families which did not harbour any mutation in exons 1-14 presented with a variety of different disease phenotypes (table 1). Eighteen families were characterised as having typical FAP with multiple colorectal polyps observed by colonoscopy or after colectomy. In eight families, patients developed additional extracolonic symptoms including osteomas (five families), detected during regular dental examination, desmoids (four families), diagnosed by computed tomography, lipomas (three families), fibromas (three families), diagnosed by careful medical examination, and upper gastrointestinal polyps (five families), mainly in the stomach observed by endoscopy. For the purposes of this report we classified these eight families as having a severe form of the disease.

In total there were four new polyposis cases with no previous family history of colorectal or upper gastrointestinal tract cancer. The selection of these cases was based on an early age of onset and the presence of multiple polyps throughout the entire colon. All these patients presented with symptoms typical of polyposis coli.
The age at which index patients were diagnosed varied from 13 to 64 years with a mean of 35.3 years.

\section{PROTEIN TRUNCATION TEST}

The in vitro synthesised protein assay was performed as described by Powell et al. ${ }^{19}$ Exon 15 of the APC gene was divided into four overlapping segments (segment $2,3,4,5$ ), as shown in fig 1 , containing codons 686 to 1217 , 1099 to 1693,1555 to 2256 , and 2131 to 2843 . The primers for amplification were designed to introduce a $\mathrm{T} 7$ promoter sequence for the initiation of transcription by T7 RNA polymerase, as well as a consensus sequence for initiation of translation. For the $50 \mu$ of PCR reaction, $200 \mathrm{ng}$ of genomic DNA was used, as well as $50 \mathrm{pmol}$ of each primer, $500 \mathrm{pmol}$ of each $\mathrm{dNTP}, 1 \mathrm{mmol} / 1$ (for segment 4 ) or $2 \mathrm{mmol} / 1$ (for segments $2,3,5$ ) $\mathrm{MgCl}_{2}, 2 \mathrm{U}$ Taq polymerase, and $1 \times$ reaction buffer ( $10 \mathrm{mmol} / 1$ Tris, $50 \mathrm{mmol} / 1 \mathrm{KCl}, 0.2 \mathrm{mg} / \mathrm{ml}$ BSA, $\mathrm{pH} 8 \cdot 5)$. The reaction parameters were 30 seconds at $94^{\circ} \mathrm{C}, 90$ seconds at $60^{\circ} \mathrm{C}$ (for segment 2 ), $62^{\circ} \mathrm{C}$ (for segment 3 ), $58^{\circ} \mathrm{C}$ (for segment 4 ), and $60^{\circ} \mathrm{C}$ (for segment 5), and 90 seconds at $70^{\circ} \mathrm{C}$ for 35 cycles.

PCR products were used directly as templates in $25 \mu \mathrm{l}$ coupled transcription-translation reaction (Promega, Madison, WI, USA) using $30 \mu \mathrm{Ci}$ of $\mathrm{S}^{35}$-methionine (Dupont, Boston, MA). Samples were incubated for 70 minutes at $30^{\circ} \mathrm{C}$, diluted in sample buffer, heated for 5 minutes at $99^{\circ} \mathrm{C}$, and analysed on $12 \%$ SDS/ polyacrylamide gel. The gels were impregnated with ENHANCE (Dupont, Boston, MA) and the proteins were visualised by autoradiography.

\section{PCR-SSCP ANALYSIS}

The polymerase chain reaction (PCR) was used to amplify genomic DNA obtained from peripheral blood lymphocytes. ${ }^{21}$ Primer sets used to amplify exon 15 of the APC gene were as previously described. ${ }^{6}$ Briefly, $10 \mu \mathrm{l}$ PCR 
A

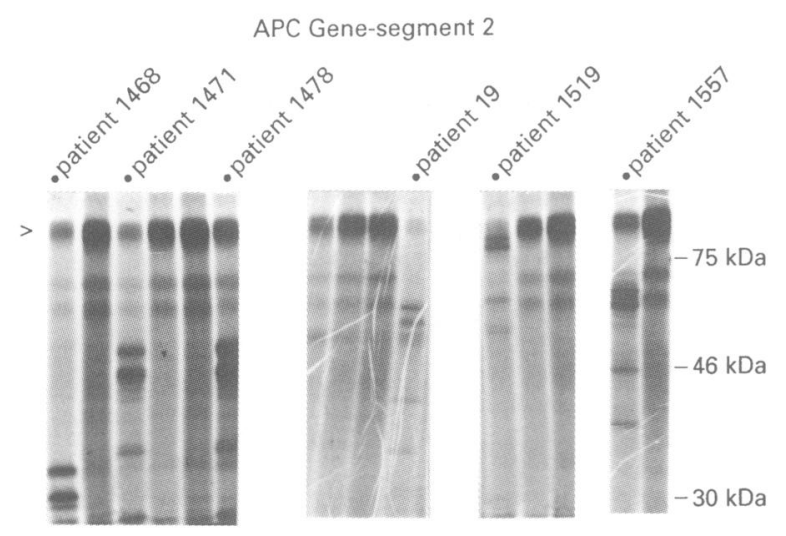

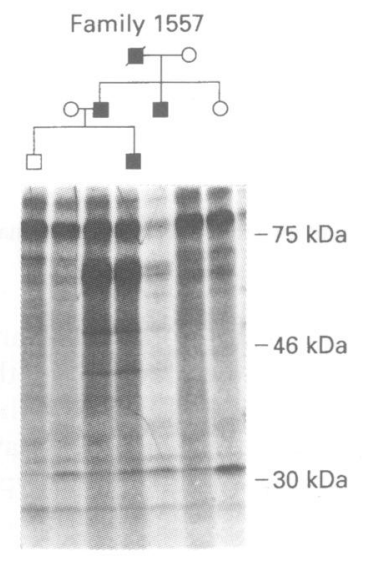

B

APC Gene-segment 3
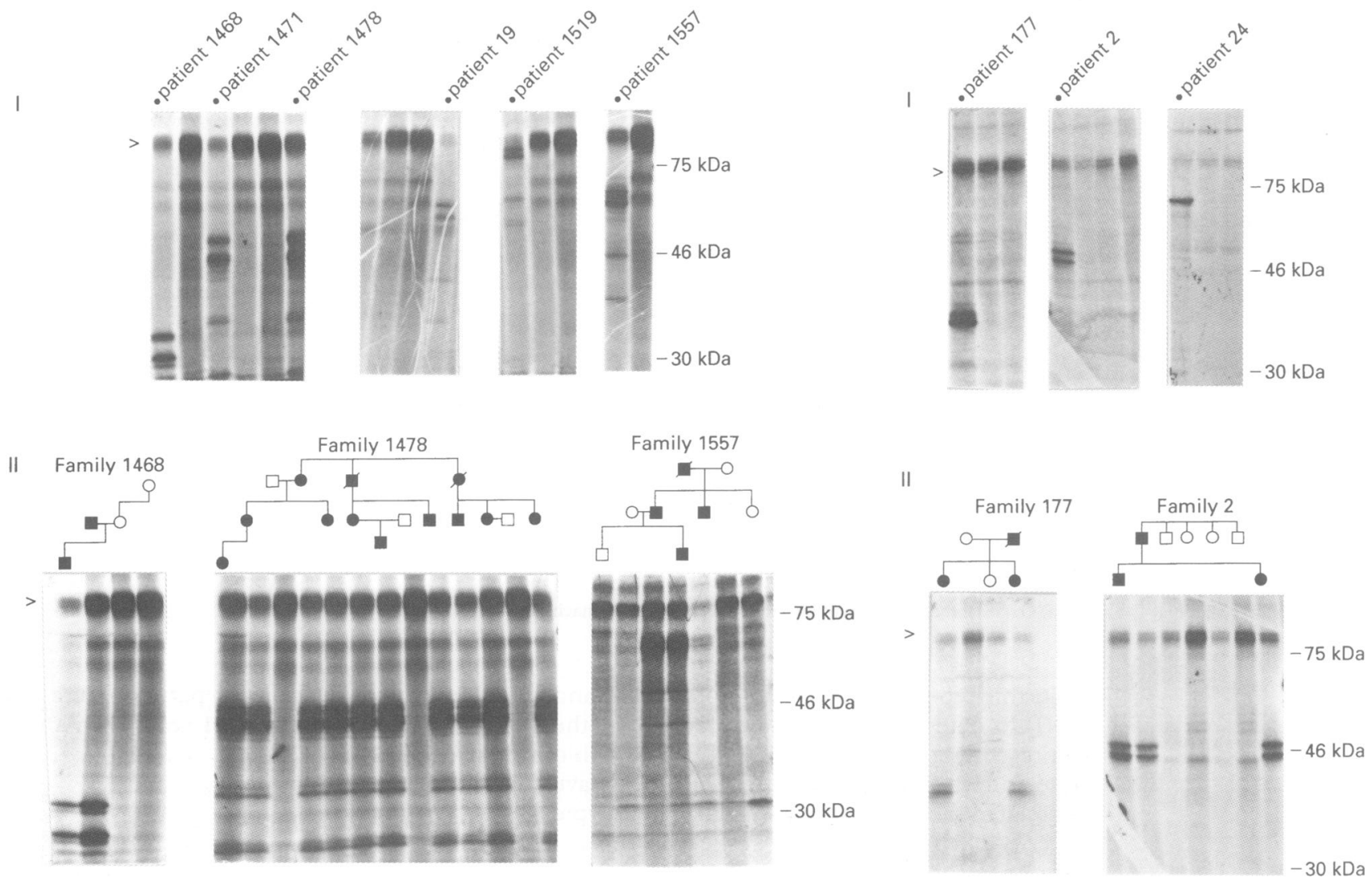

APC Gene-segment 4

C
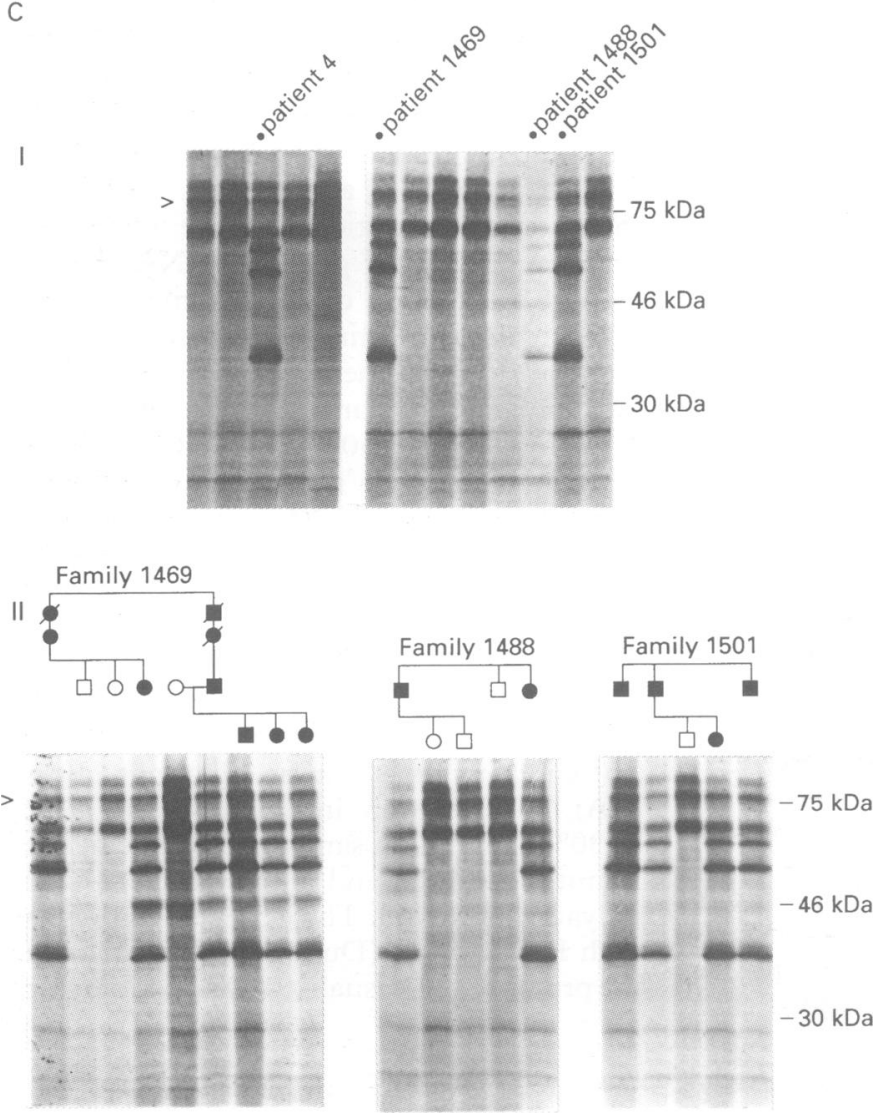

Figure 1 I. PTT of segments 2 (A), 3 (B), and 4 (C) in unrelated polyposis coli patients. The arrows mark the bands representing the expected wild type protein. II. Cosegregation analysis using PTT in families where truncated proteins were observed. Other relatives from families 1471, 19, 1519, 24, and 4 were not available for study.

reaction mixture contained $200 \mathrm{ng}$ genomic DNA, $0.5 \mu \mathrm{mol} / 1$ each primer, $2.5 \mu \mathrm{mol} / 1$ each $1 \times$ reaction buffer $(10 \mathrm{mmol} / 1$ Tris, $50 \mathrm{mmol} /$ $1 \mathrm{KCl}, 0.2 \mathrm{mg} / \mathrm{ml} \mathrm{BSA}, \mathrm{pH} 8 \cdot 5)$, and $0.1 \mu \mathrm{l}$ of dNTP, $5 \mathrm{mmol} / 1 \mathrm{MgCl}_{2}, 0.2 \mathrm{UTaq}$ polymerase, $3000 \mathrm{Ci}\left(\alpha{ }^{32} \mathrm{P}\right) \mathrm{dCTP} / \mathrm{mmol}$ (Dupont, Boston, 
MA). The reaction parameters were one minute at $93^{\circ} \mathrm{C}, 30$ seconds at $50^{\circ} \mathrm{C}$, and one minute at $72^{\circ} \mathrm{C}$ for 19 cycles.

PCR products were diluted $1: 10$ in denaturing buffer ( $95 \%$ formamide, $20 \mathrm{mmol} / 1$ EDTA, $0.05 \%$ bromphenol blue, and $0.05 \%$ xylene cyanol), heated at $80^{\circ} \mathrm{C}$ for two minutes, and applied to a 5\% non-denaturing polyacrylamide gel. Electrophoresis was performed at $6 \mathrm{~W}$ constant power at $4^{\circ} \mathrm{C}$ for eight to 11 hours. Thereafter, the gels were dried and autoradiographed.

\section{DNA SEQUENCING}

New SSCP conformers were further investigated by sequencing. DNA was amplified using the same primers as those for PCR-SSCP, purified using a QIAGEN Gel Extraction Kit (Qiagen, Inc, Chatsworth, CA), and sequenced with the dideoxy chain termination reaction using Sequenase Version 2.0 DNA Sequencing Kit (United States Biochemical Co, Cleveland, $\mathrm{OH}$ ) according to the manufacturer's instructions.

\section{Results}

Using both PTT and SSCP analysis, the entire coding region of exon 15 of the APC gene was examined for the presence of germline mutations in 31 unrelated polyposis coli families. If samples from family members were available, new bands were tested for cosegregation with the disease phenotype. New conformers were sequenced to determine the precise site and type of mutation.

The five families in whom we previously reported a mutation ${ }^{18}$ in exons 1-14 did not show any additional anomaly within the APC gene.

Using the PTT, 12 truncating mutations were detected in the remaining 26 FAP patients. Six families harboured a causative mutation in segment 2 (fig 1A) and DNA sequencing showed alterations in codons 935, 1061 (two families), 1062, 1135, and 1193. In three families a protein truncation was detected in segment 3 (fig 1B) involving codons 1403, 1450, and 1465. A further three families showed an additional protein band in segment 4 (fig 1C) which corresponded to a $1 \mathrm{bp}$ deletion in codon 1987. This mutation appears to be unique to the Swiss population. ${ }^{22}$ Studies of segment 5 showed no protein variants.

In six additional families, APC mutations in codons 793, 805, 1324 (two families), 1373, and 1393 were identified only by SSCP and confirmed by sequence analysis.

Codons 1961 and 1465 were considered to be APC mutational hot spots and in the current study we observed three families harbouring the mutations in either one of these two codons. Interestingly, no mutation was observed in the most frequently described site at codon 1309 . As far as we can ascertain, mutations in codons $805,1135,1324,1373,1393$, and 1403 have not been previously published.

In total, germline mutations in exon 15 were observed in 18 polyposis coli families representing $58 \cdot 1 \%$ of our collection. The summary of these mutations (and mutations determined within the same set of families in exons $1-14$ as described previously ${ }^{18}$ ) are listed in table 1 with their corresponding phenotypes. Altogether, disease causing APC mutations were identified in 23 of 31 screened FAP families, representing $74 \cdot 2 \%$. The remaining eight families did not appear to harbour any APC gene mutation.

There was no correlation observed between the number of polyps in the patients and the location of the APC mutation in exon 15.

Interestingly, in our data set, patients from families harbouring mutations $5^{\prime}$ of codon 1393 presented with typical FAP but no extracolonic disease to date. Mutations in segments 3 and 4 (in codons 1403-1478), however, cosegregated with a more complicated phenotype. Twentyone subjects from six families were identified who had germline mutations within this region of the APC gene (table 2). Eleven of these people developed various extracolonic lesions. Eight of them have not presented so far with 
Table 2 Families with extracolonic symptoms and identified APC germline mutation

\begin{tabular}{|c|c|c|c|c|}
\hline \multirow{2}{*}{$\begin{array}{l}\text { Family } \\
\text { No }\end{array}$} & \multirow{2}{*}{$\begin{array}{l}\text { Patient's } \\
\text { sex }\end{array}$} & \multirow[t]{2}{*}{ Present age } & \multicolumn{2}{|l|}{ Phenotype } \\
\hline & & & Polyposis & Extracolonic manifestations \\
\hline \multirow[t]{3}{*}{177} & $\mathrm{M}$ & 44 (dead) & + & Desmoid \\
\hline & $\mathrm{F}$ & & + & Desmoid, osteoma \\
\hline & $\mathrm{F}$ & 15 & + & Osteoma \\
\hline \multirow[t]{3}{*}{2} & $\mathrm{M}$ & 39 & + & Osteoma, fibroma, lipoma \\
\hline & M & 13 & + & 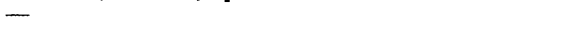 \\
\hline & $\mathrm{F}$ & 11 & - & - \\
\hline \multirow[t]{3}{*}{24} & $\mathrm{M}$ & 70 & + & Stomach polyps \\
\hline & $\mathrm{F}$ & 45 & + & Stomach and small intestinal polyps \\
\hline & $\mathrm{F}$ & 25 & + & - \\
\hline \multirow[t]{6}{*}{1469} & $\mathrm{~F}$ & 66 & + & Osteoma, lipoma, stomach and small intestinal polyps \\
\hline & $\mathrm{F}$ & 24 & + & - \\
\hline & $\mathrm{M}$ & 38 & + & Stomach and small intestinal polyps \\
\hline & M & 13 & - & - \\
\hline & $\mathrm{F}$ & 12 & - & - \\
\hline & $\mathrm{F}$ & 10 & - & - \\
\hline \multirow[t]{2}{*}{1488} & $M$ & 48 & + & Desmoid, osteoma, fibroma, stomach polyps \\
\hline & $\mathrm{F}$ & 43 & No data & \\
\hline \multirow[t]{3}{*}{1501} & $M$ & 41 & + & Desmoid, fibroma, stomach polyps \\
\hline & $M$ & 48 & & Stomach polyps \\
\hline & $\begin{array}{l}\mathrm{M} \\
\mathrm{F}\end{array}$ & $\begin{array}{l}46 \\
25\end{array}$ & $\begin{array}{l}\text { No data } \\
+\end{array}$ & - \\
\hline
\end{tabular}

any extracolonic symptom; however, they are all younger than 25 years of age. Two patients were unavilable for further investigation.

\section{Discussion}

The in vitro synthetic protein (IVSP) assay or the protein truncation test (PTT) is a recently described method for the identification of protein truncating mutations in the APC gene. This is by virtue of the fact that $97 \%$ of all APC mutations reported to date result in premature stop codons. ${ }^{23}$

There are, however, problems with the sensitivity of the technique, as in our hands $33 \%$ of our confirmed truncating mutations in exon 15 were not detected using PTT. One explanation that accounts for the failure to detect mutations occurring close to the $5^{\prime}$ end of the segments is the small size of the mutated protein product, which may not be as efficiently translated as the expected wild type product. Alternatively, or in addition, the resolving capacity of the acrylamide gel may not be sufficient to detect small protein products as even on a $10-20 \%$ gradient gel these predicted synthetic peptides were not observed.

As all mutations detected by PTT were confirmed by SSCP it was possible to calculate the relative percentage of mutations detected using the two methods. From the 18 confirmed mutations in exon $15,66 \%$ were detected by PTT and $94 \%$ by SSCP. Therefore, we conclude that SSCP is more sensitive than PTT. As, however, the PTT is rapid and simple we can recommend its application, at least in the first phase of APC mutation screening.

Even though two detection methods were used to establish the presence of APC germline mutations, eight FAP families did not appear to harbour mutations in the coding region of the APC gene. Several explanations could account for this finding. Owing to there being splice site variation in the APC gene, an intron/ exon splice acceptor or donor mutation may give rise to an aberrant misspliced variant, which may not be identified by some of the oligonucleotides used in this study. ${ }^{6}$ In ad- dition, mutations occurring in promoter or enhancer regions may also account for the failure to detect mutations.

Several reports have been published attempting to correlate the clinical variability of FAP with a particular location of mutations in the APC gene.

The presence of germline mutations in the very $5^{\prime}$ region of the APC gene appears to correlate with a smaller number of polyps and slower disease progression. ${ }^{1718}$ These mutations give rise to very short proteins, which are probably unable to dimerise with wild type monomers and therefore do not act in a dominant negative manner. Spirio et al ${ }^{17}$ suggested a functional boundary within the APC gene (codons 157-168) that determines the phenotypic characteristics of typical FAP and AAPC families. Interestingly, probably not all mild cases of polyposis coli are related to this APC region as some could arise as a result of any mutation within the gene which presumably does not significantly alter APC function. ${ }^{22}$

A profuse number of colorectal polyps appeared to be associated with mutations located between codons $1250-1464$ of the APC gene. ${ }^{24}$ Several authors found that families with mutations in codon 1309 and $3^{\prime}$ of it tend to have a more severe disease phenotype with an earlier onset of colonic disease and extracolonic symptoms. ${ }^{25-27}$ Very recently, Caspari et al ${ }^{28}$ showed that patients with mutations between codons 1445-1578 generally tend to develop osteomas, epidermoid cysts, upper gastrointestinal polyps, and desmoid tumours. Scott $e t a l^{22}$ observed a large family with a unique mutation in the APC gene (codon 1987) presenting with a variety of phenotypes including variable polyp number and frequently extracolonic disease.

Several groups, ${ }^{2329-32}$ however, did not observe any correlation between the mutation site and extracolonic manifestations of FAP and presumed that these were not associated with the type or location of the mutation. The majority of these studies, however, did not report mutations beyond codon 1403 as these are relatively rare. 
Mutations from exon 4 to codon 1393 in exon 15 resulted in a typical FAP phenotype in our data set, but this is probably not significant as several reports have been published indicating that mutations occurring in this region can also result in a severe phenotype. ${ }^{263132}$ Interestingly, all six families (11 patients) harbouring mutations downstream and including codon 1403 were clinically associated with the more severe form of the disease. Only mutation carriers who were younger than 25 years of age were free of extracolonic symptoms. This appears to be significant, as to our knowledge there has been no report indicating that typical disease without additional extracolonic lesions is associated with a mutation located beyond codon 1403.

So far there is no evidence to explain why these mutations lead to the expression of an unpredictable and often severe disease phenotype. One proposal could be that truncations beyond codon 1403 give rise to a protein that is incapable of associating with microtubules, but is able to bind to catenin (fig 2), thus effecting the physiological role of catenin. Alternatively, a more severe disease phenotype could be a result of a lack of $\beta$-catenin downregulating activity even though catenin binding activity is still present.

Disease expression could alternatively be the result of a modifying gene that may either suppress or enhance disease characteristics. In favour of this explanation are experiments with the Min mouse (multiple intestinal neoplasia) which harbours an Apc mutation (murine homologue of APC). ${ }^{33-36}$ The results of these studies indicate the presence of a modifying gene, ${ }^{37}$ which affects, at least, tumour multiplicity. Very recently, a candidate gene was reported, namely, secretory type II phospholipase A2. ${ }^{38}$ Additionally, the presence of other modifying loci appears to be the most likely explanation. Some mutations may, however, be so dominant that modifier genes may not strongly influence disease expression. Therefore similar phenotypes between different persons carrying the same mutation may still be observed, as appears to be the case for mutations at codon $1309 .^{26}$

In conclusion, we report the identification of 23 APC germline mutations in a set of 31 polyposis coli patients. To perform this mutational screening we applied both SSCP analysis and the recently described PTT. We believe that the PTT is a rapid and reliable alternative as an initial screen compared to other methods. SSCP analysis, although more tedious, appears to be a more reliable method of mutation detection. We observed an apparent correlation between the location of APC mutations beyond codon 1403 and extracolonic disease in polyposis coli patients.

This work was supported by Swiss National Foundation grants 32-300007.90 and 32-32556.91, the Julius Klaus-Stiftung, the Kamillo Eisner Stiftung, Hergiswil, and the Swiss Cancer League AKT78. Additionally, we would like to acknowledge all the medical doctors who supplied us with material and the families who participated in this study.

1 Bülow S. Familial polyposis coli. Dan Med Bull 1987;34 $1-15$
2 Bodmer WF, Baily CJ, Bodmer J, et al. Localization of the gene for familial adenomatous polyposis on chromosome gene for familial adenomato

3 Leppert M, Dobbs M, Scambler P, et al. The gene for familial polyposis coli maps to the long arm of chromosome 5. Science 1987;238:1411-13.

4 Kinzler KW, Nilbert MC, Su L, et al. Identification of FAP locus genes from chromosome 5q21. Science 1991;253 $661-5$.

5 Joslyn G, Carlson M, Thliveris A, et al. Identification of deletion mutations and three new genes at the familial polyposis locus. Cell 1991;66:601-13.

6 Groden J, Thliveris A, Samowitz W, et al. Identification and characterization of the familial adenomatous polyposis coli gene. Cell 1991;66:589-600

7 Su L, Johnson KA, Smith KJ, Hill DE, Vogelstein B, Kinzler KW. Association between wild type and mutant APC gene products. Cancer Res 1993;53:2728-31.

8 Rubinfeld B, Souza B, Albert I, et al. Association of the APC gene product with $\beta$-catenin. Science 1993;262:1731-4 9 Su L, Vogelstein B, Kinzler KW. Association of the APC tumor suppressor protein with catenins. Science 1993 262:1734-7.

10 Polakis P. Mutations in the APC gene and their implications for protein structure and function. Curr Opin Genet Dev 1995;5:66-71.

11 Rubinfeld B, Souza B, Albert I, Munemitsu S, Polakis $P$. The APC protein and E-cadherin form similar but independent complexes with $\alpha$-catenin, $\beta$-catenin, and independent complexes with $\alpha$-catenin, $\beta$-cate

12 Munemitsu S, Albert I, Souza B, Rubinfeld B, Polakis P. Regulation of intracellular $\beta$-catenin levels by the adenomatous polyposis coli (APC) tumor-suppressor protein. Proc Natl Acad Sci USA 1995;92:3046-50.

3 Munemitsu S, Souza B, Müller P, Albert I, Rubinfeld B, Polakis P. The APC gene product associates with microtubules in vivo and promotes their assembly in vitro. Cancer Res 1994;54:3676-81.

14 Smith KJ, Levy DB, Maupin P, Pollard D, Vogelstein B, Kinzler KW. Wild-type but not mutant APC associates with the microtubule cytoskeleton. Cancer Res 1994;54: with the

15 Spirio L, Otterud B, Stauffer D, et al. Linkage of a variant or attenuated form of adenomatous polyposis coli to the adenomatous polyposis coli (APC) locus. Am f Hum Genet 1992;51:92-100

16 Lynch HT, Smyrk TC, Lanspa SJ, et al. Upper gastrointestinal manifestations in families with hereditary flat adenoma syndrome. Cancer 1993;71:2709-14.

17 Spirio L, Olschwang S, Groden J, et al. Alleles of the APC gene: an attenuated form of familial polyposis. Cell 1993 75:951-7.

18 Dobbie Z, Spycher M, Hürliman R, et al. Mutational analysis of the first 14 exons of the adenomatous polyposis coli (APC) gene. Eur 7 Cancer 1994;30:1709-13.

19 Powell SM, Petersen GM, Krush AJ, et al. Molecular diagnosis of familial adenomatous polyposis. $N$ Engl $f \mathrm{Med}$ 1993;329:1982-7.

20 van der Luijt R, Meera Khan P, Vasen H, et al. Rapid detection of translation-terminating mutations at the adenomatous polyposis coli (APC) gene by direct protein truncation test. Genomics 1994;20:1-4.

21 Miller SA, Dykes DD, Polesky HF. A simple salting out procedure for extracting DNA from human nucleated cells. Nucleic Acids Res 1988;16:739.

22 Scott RJ, van der Luijt R, Spycher M, et al. Novel germline APC mutation in a large familial adenomatous polyposis kindred displaying variable phenotypes. Gut 1995;36:7316.

23 Nakamura Y. The role of the adenomatous polyposis coli (APC) gene in human cancers. Adv Cancer Res 1993;62: $65-87$

24 Nagase H, Miyoshi Y, Horii A, et al. Correlation between the location of germ-line mutations in the APC gene and the number of colorectal polyps in familial adenomatous polyposis patients. Cancer Res 1992;52:4055-7.

25 Caspari R, Friedl W, Mandl M, et al. Familial adenomatous polyposis: mutation at codon 1309 and early onset of colon cancer. Lancet 1994;343:629-32.

26 Gayther SA, Wells D, SenGupta SB, et al. Regionally clustered APC mutations are associated with a severe phenotype and occur at a high frequency in new mutation phenotype and occur at a high frequency in new mutation 3:53-6.

27 Nugent KP, Phillips RKS, Hodgson SV, et al. Phenotypic expression in familial adenomatous polyposis: partial prediction by mutation analysis. Gut 1994;35:1622-3.

28 Caspari R, Olschwang S, Friedl W, et al. Familial adenomatous polyposis: desmoid tumors and lack of ophthalmic lesions (CHRPE) associated with APC mutations beyond codon 1444. Hum Mol Genet 1995;4:337-40.

29 Paul P, Letteboer T, Gelbert L, Groden J, White R, Coopes $M$. Identical APC exon 15 mutations result in a variable phenotype in familial adenomatous poylposis. Hum Mol Genet 1993;2:925-31.

30 Gurbuz AK, Giardello FM, Petersen GM, et al. Desmoid tumors in familial adenomatous polyposis. Gut 1994;35: 377-81.

31 Prosser J, Condie A, Wright M, et al. APC mutation analysis by chemical cleavage of mismatch and a protein truncation assay in familial adenomatous polyposis. Br F Cancer 1994;

32 Groden J, Gelbert L, Thliveris A, et al. Mutational analysis of patients with adenomatous polyposis: identical in- 
activating mutations in unrelated individuals. $\mathrm{Am}$ f $\mathrm{Hum}$ Genet 1993;52:262-72.

33 Moser AR, Pitot HC, Dove WF. A dominant mutation that predisposes to multiple intestinal neoplasia in the mouse. ience 1990;247:322-4.

34 Moser AR, Dove WF, Roth KA, Gordon JI. The MIN (multiple intestinal neoplasia) mutation: its effects on gut epithelium cell differentiation and interaction with modifier system. 7 Cell Biol 1992;116:517-26.

35 Su L, Kinzler KW, Vogelstein B, et al. Multiple intestinal neoplasia caused by a mutation in the murine homolog of the APC gene. Science 1992;256:668-70.
36 Luongo C, Gould KA, Su L, et al. Mapping of multiple intestinal neoplasia (Min) to proximal chromosome 18 of

37 Deitrich WF, Lander ES, Smith JS, et al. Genetic identification of Mom-1, a major modifier locus affecting Mintification of Mom-1, a major modifier locus affecting Min-
induced intestinal neoplasia in the mouse. Cell 1994;75: 631-9.

38 MacPhee M, Chepenik KP, Liddeli RA, Siracusa LD, Buchberg AM. The secretory phospholipase A2 gene is a candidate for Mom 1 locus, a major modifying of APC $^{\text {Min }}$-induced intestinal neoplasia. Cell 1995;81:95766 . 